УДК: 351: 330.522 .4

\author{
Подобєд Ігор, \\ ORCID iD 0000-0001-6779-2717 \\ E-mail : ipodobed21@gmail.com
}

\title{
НОРМАТИВНО-ПРАВОВЕ ЗАБЕЗПЕЧЕННЯ РОЗВИТКУ МАТЕРІАЛЬНО-ТЕХНІЧНОГО ПОТЕНЦАЛУ ЄДИНОЇ ДЕРЖАВНОЇ СИСТЕМИ ЦИВІЛЬНОГО ЗАХИСТУ
}

\section{https://doi.org/10.32689/2618-0065-2021-1(7)-216-241}

Анотація. Практика реагування на надзвичайну ситуацію, що пов'язана із розповсюдженням захворюваності населення COVID-19, свідчить, що ефективність функціонування Єдиної державної системи цивільного захисту в повсякденному режимі, а особливо при переведенні ії в режим надзвичайної ситуації залежить від наявності в неї відповідного ресурсного потенціалу.

Метою статті $\epsilon$ аналіз стану нормативно-правового забезпечення розвитку матеріально-технічного потенціалу ЄДСЦЗ. На основі аналізу різних методологічних підходів державного управління сферою цивільного захисту перспективним запропоновано застосування ресурсного підходу до функціонування ЄДСЦЗ. Це дозволяє враховувати прогнози щодо ії розвитку, прогнозувати застосування нових та альтернативних видів ресурсів.

Подається авторське розуміння дефініцій «ресурс», «потенціал», «ресурсний потенціал», «матеріально-технічний ресурс». У статті дано авторське визначення ресурсного потенціалу СДС ЦЗ як комплексу науково-технічного, морального, організаційного, кадрового, фінансового, матеріально-технічного, освітнього, інформаційного, інституційного (соціально-інфраструктурного) потенціалу, що може бути застосований органами управління для виконання іiі функцій. Матеріально-технічний ресурс (потенціал) розуміється як сукупність матеріальних і технічних засобів, технологій, систем, що створюють систему ресурсного забезпечення функціонування ЄДСЦЗ. По суті матеріальнотехнічний ресурс складається із поточного ресурсу, що використовуються ЄДСЦЗ, а також матеріальних резервів, що відповідно до законодавства поділяються на оперативний, відомчий, регіональний та об'єктовий. Також для виконання завдань ліквідації наслідків надзвичайних ситуацій може залучатися державний матеріальний резерв. Визначено, що нормативноправове забезпечення розвитку матеріально-технічного потенціалу ЄДСЦЗ в достатній мірі регламентовано. Однак встановлено, що фактичний стан матеріально-технічного ресурсу ЄДСЦЗ не забезпечує вчасного, належного забезпечення реалізації заходів із запобігання чи ліквідації наслідків в умовах надзвичайних ситуацій. Критеріями оцінювання стану розвитку ресурсного 
потенціалу ЄДСЦЗ є доцільність і ефективність використання будь-яких із наявних ресурсів, ефективність управління на всіх рівнях - державному, функціональному, територіальному, об’єктовому.

Напрямом подальшого визначено розробка алгоритму розрахунку рівня ефективності управління розвитком ресурсного потенціалу ЄДСЦЗ.

Ключові слова: державне управління, ресурсний потенціал, структура ресурсного потенціалу, Єдина державна система цивільного захисту, матеріальні резерви, надзвичайна ситуація, цивільний захист, нормативноправове забезпечення.

Постановка проблеми. Практика реагування на надзвичайну ситуацію, що пов'язана із розповсюдженням захворюваності населення COVID-19, свідчить, що ефективність функціонування Єдиної державної системи цивільного захисту в повсякденному режимі, а особливо при переведенні іiі в режим надзвичайної ситуації залежить від наявності в неї відповідного ресурсного потенціалу.

Існують різні методологічні підходи державного управління сферою цивільного захисту (інституціональний, системний, організаційно-функціональний тощо). Важливим, на нашу думку, $\epsilon$ те, що саме ресурсний підхід дозволяє «...виявити межі корисності того чи іншого елементу системи в досягненні цілі в умовах конкретної ситуації (існуючі технології та соціальноекономічні відносини) з урахуванням ієрархії цінностей ресурсів і законів заміщення» [1].

Під ресурсним потенціалом СДСЦЗ (визначення автора буде обгрунтовано нижче) будемо розуміти комплекс науковотехнічного, морального, кадрового, фінансового, матеріальнотехнічного, інформаційного, інституційного (соціальноінфраструктурного) потенціалу, що може бути застосований органами управління для виконання іiі функцій.

Саме ресурсний потенціал ЄДСЦЗ визначає іiі потенційні можливості щодо виконання законодавчо передбачених функцій.

Державною службою України 3 надзвичайних ситуацій (далі - ДСНС) неодноразово вказувалося на необхідності підвищення ресурсного потенціалу функціональних та територіальних підсистем Єдиної державної системи цивільного захисту під час перевірок. Але, користуючись результатами 
дослідження С. Литвиновського, нажаль поодинокого (принаймні нам відомого), акти перевірок залишились не реалізованими [2, c. 168].

Отже, науковою проблемою, що вимагає негайного розв'язання, $є$ проблема пошуку шляхів організаційно-правового регулювання розвитком ресурсного потенціалу СДСЦЗ.

Аналіз останніх досліджень і публікацій. Теоретичним та методологічним підгрунтям нашого дослідження $\epsilon$ праці науковців з проблематики особливостей державного управління у сфері цивільного захисту (С. Андрєєв, М. Андрієнко, П. Волянський, О. Лещенко А. Терент'єва, А. Титаренко та ін.)

Зауважимо, що хоча перелік наукових праць 3 напряму державного управління сферою цивільного захисту 3 кожним роком поповнюється, однак, погоджуємося з С. Андреєвим, який, посилаючись на Ю. Сурміна та П. Надолішнього, ще у 2016 році визначав стан розвитку методології державного управління у сфері Ц3, як недостатній з точки зору розвиненості методології, методів, інструментів, механізмів, технологій наукового пізнання, та такий, що не задовольняє потреби практики державного управління у сфері цивільного захисту [3]. Нажаль, ця проблема в повному обсязі не вирішена і сьогодні, а враховуючи перманентні зміни в турбулентному світі не втратить актуальності й у найближчі десятиліття.

Розвитку методології дослідження державного управління у сфері цивільного захисту, пошуку визначення методологічних підходів присвячена низка досліджень і публікацій, що ми покладаємо в теоретичну основу нашого дослідження.

Насамперед, це дисертаційне дослідження С. Андрєєва [4]. Науковець обгрунтував, що «інституціональний підхід до розвитку державних систем ЦЗ базується на взаємозалежності та взаємозв'язку двох основних складових - інституційної (підсистем, ланок, органів державної влади, органів місцевого самоврядування (ОМС), сил ЦЗ тощо) та нормативно-правової (законах, підзаконних нормативно-правових актах тощо), які $\epsilon$ базовими елементами, що формуються суспільством і державою 3 
метою якомога ефективнішого забезпечення захисту від загроз, пов'язаних із ризиком виникнення різних НС» $[4$, с. 5] .

Важливим висновком дослідження С. Андрєєва, що актуалізує наше дослідження, $є$ висновок про «чинники, що деструктивно впливають на інституціональний розвиток ЄДС ЦЗ: кадрові, матеріально-технічні, науково-освітні, організаційноуправлінські, політичні, правові, фінансово-економічні. Це в сукупності зумовлює низьку ефективність СДСЦЗ та отримання від неї «системного ефекту» [4, с. 5]. Як бачимо, серед цих чинників визначені нами компоненти ресурсного потенціалу, серед них i матеріально-технічний, про нормативно-правове забезпечення розвитку якого йдеться в цій статті.

Актуальність нашого дослідження підтверджується i результатами дослідження А. Титаренко. Серед основних напрямів державної політики у сфері запобігання $\mathrm{HC}$ i забезпечення безпеки населення та територій автор визначає удосконалення матеріально-технічного забезпечення діяльності зі зниження ризиків та пом'якшення $\mathrm{HC}$, а також підвищення ефективності заходів 3 їх усунення [5, с. 221]. Науковець зазначає, що «Роботи із запобігання НС мають здійснюватися у вигляді взаємопов'язаних правових, організаційних, економічних, наукових і технічних заходів» [5, с. 222]. А серед основних принципів захисту населення i територій у випадку загрози i виникнення НС, що важливо для обгрунтування ресурсного підходу та визначення структури ресурсного потенціалу ЄДСЦЗ - принцип необхідної достатності та максимально можливого використання наявних сил і засобів визначає обсяг заходів щодо захисту населення і територій у разі загрози НС.

О. Лещенко в дослідженні «Трансформація системи цивільного захисту України в умовах сучасних воєннополітичних конфліктів гібридного типу» сформульовані основні принципи модернізації вітчизняної системи ЦЗ: універсальності, завчасності, інституційної ефективності, оперативної готовності та мобільності, достатності, пріоритету запобігання, інтеграції та добровільності. Визначено основні концептуальні напрямки трансформації ЄДС ЦЗ в сучасних безпекових умовах, зокрема: 
розвиток спроможностей сил ЦЗ (ресурсного потенціалу I. Подобед); визначення економічно обгрунтованих та оптимальних обсягів реалізації заходів захисту населення i територій від НС (оптимальне використання матеріальнотехнічного потенціалу СДСЦЗ - І. Подобед); розвиток мобілізаційних спроможностей суб' єктів забезпечення ЦЗ (у тому числі накопиченого ресурсного потенціалу - I. Подобед); залучення всіх ключових стейкхолдерів до реалізації превентивних та оперативних заходів ЦЗ. [6, с. 11].

П. Волянський, розробляючи авторську концепцію державного управління медичним захистом у надзвичайних ситуаціях в структурі медичного захисту, визначає такі компоненти: нормативно-правовий, організаційний, фінансовий, інформаційний, матеріально-технічний [7, с. 310].

В рамках реалізації мети нашої статті треба зазначити, що автор серед основних завдань системи медичного захисту ЄДСЦЗ визначає: накопичення та утримання визначених запасів медичного, санітарно-господарського та спеціального майна; планування раціонального використання існуючих медичних сил і засобів системи медичного захисту [7, с. 284]. Тобто, знов мова ведеться про накопичення та раціональне використання матеріально-технічного потенціалу, в даному випадку системи медичного захисту СДСЦЗ.

А. Терент'єва серед основних завдань управління в умовах НС визначає організацію ресурсного забезпечення сил і засобів [8, c. 343].

Аналіз наявних публікацій свідчить, що саме А. Терент'євою на початку 2000 років зроблено спробу обгрунтування економічно-математичної моделі управління матеріальними ресурсами Державної служби медицини катастроф [9], розроблений алгоритм визначення необхідних ресурсів для подолання наслідків НC [10]. Ці праці також стануть теоретичним підгрунтям реалізації завдань нашого дослідження.

Частково проблематика ресурсного забезпечення при обгрунтуванні механізму державного управління сферою 
пожежної безпеки дотично розглянута у дослідженні М. Андрієнко [21].

Враховуючи міждисплінарний характер науки державного управління, необхідним вважаємо аналіз досліджень суміжних наукових дисциплін, зокрема економіки.

Проблематика управління ресурсним потенціалом розглядається в межах розв'язання питань управління економікою, регіоном, підприємством.

Управління ресурсним потенціалом підприємства - це безперервний, динамічний, цілеспрямований процес, який полягає у впливі суб'єкта управління ресурсним потенціалом на об'єкт на основі застосування функцій, принципів, методів і процедур управлінського характеру, 3 метою досягнення ефективнішого залучення, використання та розвитку ресурсного потенціалу підприємства [11].

Управління ресурсним потенціалом регіону у широкому розумінні, на прикладі управління людським ресурсом визначається як «...система взаємозалежних організаційноекономічних і соціальних заходів 3 метою створення умов для нормального функціонування, розвитку й ефективного використання потенціалу...» [12, с. 29].

Проблематику нормативно-правового забезпечення кадрового потенціалу ЄДСЦЗ розглядали у своїй праці П. Волянський, Є. Литвиновський, В. Михайлов [13]. Практична реалізація методичних рекомендацій авторів, як показала практика функціонування мережі навчально-методичних установ цивільного захисту, призвела до покращення підготовки кадрів (кадрового потенціалу СДСЦЗ). В першу чергу, територіальних підсистем ЄДСЦЗ. Однак, за ці роки відбулись зміни в нормативному забезпеченні, які необхідно врахувати в подальшому.

Такі ж перманентні зміни нормативно-правового забезпечення стосувались й інших компонентів ресурсного потенціалу ЄДСЦЗ.

Невипадково О. Лещенком в результатах дослідження робиться висновки щодо «...управлінських помилок у процесі 
реалізації ЦЗ як безпекової функції держави...», зокрема, що пов'язані 3 недостатнім рівень фінансового та матеріального забезпечення заходів ЦЗ [6].

Враховуючи зміст матриці перспективних напрямів досліджень проблем державного управління, що не втрачають, на нашу думку, актуальність $[14$, с. 50], удосконалення функціонування ЄДСЦЗ через обгрунтування організаційноправових, методичних засад управління розвитком іiі ресурсного потенціалу - $€$ частковим науковим завданням нашого дослідження. Розв'язання цього завдання вимагає проведення аналізу стану відповідного нормативно-правового забезпечення всіх його компонент, в тому числі матеріально-технічної (матеріального- технічного потенціалу).

Метою статті $\mathbf{\epsilon}$ аналіз стану нормативно-правового забезпечення розвитку матеріально-технічного потенціалу ЄДСЦЗ.

Виклад основного матеріалу. Для подальшого проведення дослідження необхідно визначитися з основними дефініціями, а саме: «ресурс», «потенціал», «ресурсний потенціал», «матеріально-технічний ресурс».

Як свідчить аналіз наукової літератури, зокрема [12], немає єдиного трактування таких категорій, як “ресурси” i “ресурсний потенціал”.

Ресурси, зазначено [15], це джерела й одночасно обмеження здійснення будь-якої суспільної діяльності.

Під ресурсами ЄДСЦЗ, у широкому розумінні, погоджуючись 3 колективом авторів під керівництвом М. Орлатого [цит. за 12], ми будемо розуміти реальні можливості суб'єкта (суб'єктів) управління ЄДСЦЗ щодо доцільного та раціонального використання елементів системи для досягнення у певний період часу цілей управління та реалізації державної функції цивільного захисту та виконання завдань захисту населення, запобігання, реагування та ліквідації наслідків надзвичайних ситуацій.

3 точки зору теорії державного управління ресурси в нашому дослідженні ми будемо розглядати з таких позицій: 
«...владної - фундаментальне джерело управління; атрибут, обставина або благо, володіння яким підвищує здатність впливу його володаря на інших індивідів або групу; це можливість, яка не обов'язково стає реальністю; усі ті засоби, використання яких забезпечує вплив на об'єкт відповідно до цілей суб'єкта;

соціальної - реальні та потенційні можливості, засоби і резерви, якими володіє певне суспільство і які воно використовує для забезпечення різних сфер соціального життя і діяльності;

об'єктної - елемент об’єкта управління, який може бути ефективно використаний суб'єктом для досягнення цілей; де-яка сукупність можливостей адміністративно-територіального утворення, розпорядження якими віднесено до компетенції органів влади» [цит. за 12, с. 17-18].

Підгрунтям визначення поняття «ресурсний потенціал» $\epsilon$ розуміння того, що «...потенціал - сукупність всіх наявних засобів, можливостей, продуктивних сил та ін., що можуть бути використані в якій-небудь галузі, ділянці, сфері; приховані здатності, сили для якої-небудь діяльності, що можуть виявитися при певних умовах [цит. за 16, с. 101].

Є. Литвиновським на підставі цього дано визначення кадрового потенціалу. Кадровий потенціал СДС ЦЗ - це сукупність професійних компетентностей керівних кадрів i фахівців всіх суб'єктів забезпечення цивільного захисту та їх групової активності щодо виконання завдань захисту населення, запобігання, реагування та ліквідації наслідків надзвичайних ситуацій [16, с. 102].

Цікавим для нашого дослідження, враховуючи те, що ЄДСЦЗ входить структурним елементом у сектор національної безпеки і оборони, $€$ трактування потенціалу системи забезпечення національної безпеки, що надане в енциклопедії державного управління [17]. «Потенціал системи забезпечення національної безпеки (англ. potential of the system of providing of national security) - сили і засоби, що активно використовуються в процесі вирішення загальнодержавних завдань забезпечення національної безпеки, а також потенційні можливості, які має країна в певних сферах і які можуть бути використані в разі необхідності. 
Потенціал (від лат. potentia - сила) - засоби, запаси, джерела, можливості, які $€$ в наявності, можуть бути мобілізовані i використані для вирішення певних завдань, досягнення певної мети. Певним видом цього потенціалу є така частина відповідних потенціалів, яка реально функціонує та істотно впливає на суспільні процеси залежно від конкретних умов іiі використання державними інститутами...» [17, с. 480].

Розробляючи ресурсний підхід до удосконалення функціонування ЄДСЦ3, враховуючи міждисциплінарний характер науки державного управління, вважаємо за необхідне застосувати методологію економічної науки. 3 позиції економістів характеристиками «ресурсного потенціалу» $\epsilon$ : «... ресурсний потенціал являє собою систему ресурсів, які використовуються комплексно, i передбачає обов'язкову взаємодоповнюваність окремих ресурсів у процесі суспільного виробництва; ресурсний потенціал передбачає можливість взаємозамінності ресурсів, що використовуються в суспільному виробництві. Багатофункціональність більшості видів ресурсів створює умови варіації вживання різних їх видів і елементів для досягнення одного $\mathrm{i}$ того ж самого заданого кінцевого результату; у його склад входять не тільки ресурси, призначені до споживання в певному періоді, а й їх страхові та інші запаси» [12].

Важливим для нашого дослідження $\epsilon$ те, що ресурсний потенціал визначає потенційну можливість їх використання; ресурсний потенціал характеризує не весь запас ресурсу, що є в природі або суспільстві, а тільки ту його частину, яку можна одержати 3 урахуванням досягнутого рівня технологічного розвитку та економічної доцільності. Тому в поняття “ресурсний потенціал СДСЦЗ” повинні включатися тільки такі джерела ресурсів, отримання яких можливе й ефективне на даному етапі іiі розвитку.

Однак застосування ресурсного підходу до функціонування ЄДСЦЗ дозволяє враховувати прогнози щодо їі розвитку, тобто враховувати не тільки систему ресурсів, що склалася, а й прогнозувати застосування нових та альтернативних видів 
ресурсів, можливість використання яких науково обгрунтована, i отримання (або використання) передбачено в даному періоді та на перспективу.

Отже, на підставі зазначеного, під ресурсним потенціалом СДС ЦЗ (визначення автора) будемо розуміти комплекс науковотехнічного, морального, організаційного, кадрового, фінансового, матеріально-технічного, освітньог, інформаційного, інституційного (соціально-інфраструктурного) потенціалу, що може бути застосований органами управління для виконання iii функцій.

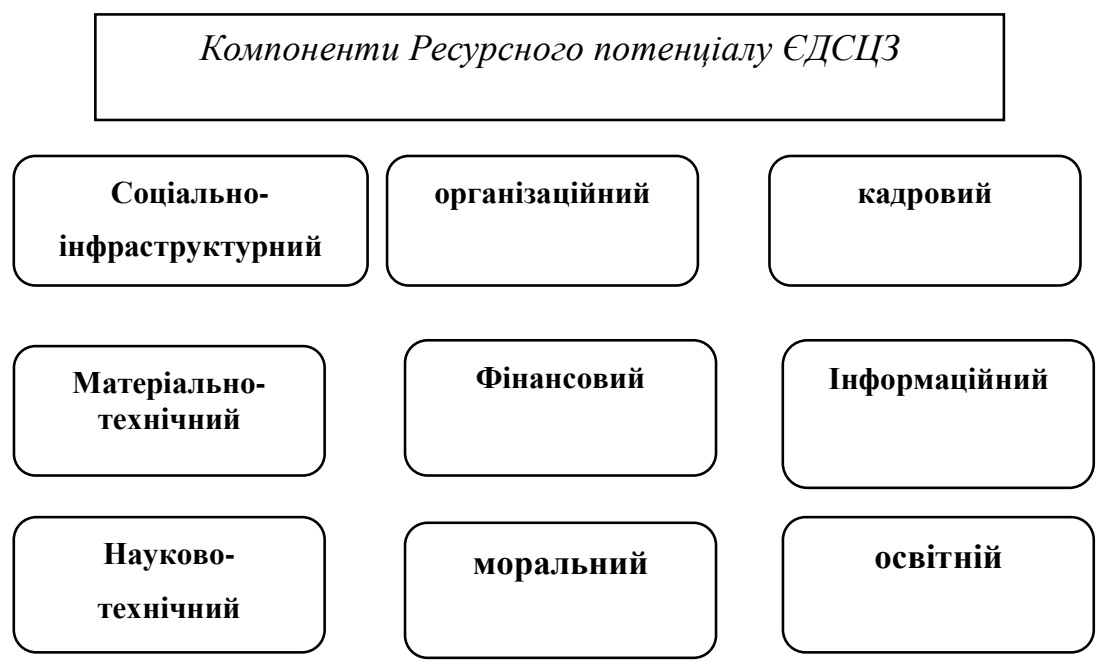

Рисунок 1 - Компоненти ресурсного потенціалу СДСЦЗ

Складено автором.

Структурні компоненти ресурсного потенціалу ЄДСЦЗ подано на рисунку 1. Визначення та напрямки розвитку кожного компоненти ресурсного потенціалу - це напрям не одного наукового дослідження. В даній публікації ми зупинимось на аналізу стану нормативно-правового забезпечення розвитку матеріально-технічного ресурсу функціонування ЄДСЦЗ.

На нашу думку, матеріально-технічний ресурс - це сукупність матеріальних і технічних засобів, технологій, систем, 
що створюють систему ресурсного забезпечення функціонування СДСЦЗ. В свою чергу, ресурсне забезпечення - це система організаційно-економічних відносин між суб'єктами забезпечення цивільного захисту, спрямованих на своєчасне та ефективне забезпечення функціонування СДСЦЗ необхідними ресурсами.

Треба розрізняти ресурсне забезпечення ЄДСЦЗ в різних режимах іiі функціонування. Особливо це стосується в межах виконання завдань щодо створення, накопичення та використання матеріальних резервів для запобігання та ліквідації наслідків надзвичайних ситуацій. Саме зволікання 3 накопиченням резервів, як показує практика, є одним із головних факторів неефективного функціонування ЄДСЦЗ в режимі повсякденного функціонування, i тим більше в режимі надзвичайної ситуації.

У прямій постановці поняття «матеріально-технічний ресурс» в Кодексі цивільного захисту не визначено. Однак, питанням матеріально-технічного забезпечення присвячено окрему главу (глава 21) [18]. Також зазначено, що суб'єкти забезпечення, у першу чергу Центральний орган виконавчої влади, який забезпечує формування та реалізує державну політику у сфері цивільного захисту, визначає потребу в фінансових та матеріально-технічних ресурсах органів та підрозділів цивільного захисту для виконання ними завдань особливого періоду та у разі проведення цільової мобілізації, подає відповідні пропозиції до центрального органу виконавчої влади, який забезпечує формування та реалізує державну політику у сфері економічного і соціального розвитку [18, ст. 17 п. 14]. А завданням і обов'язкам суб'єктів господарювання $\epsilon$ створення необхідної для функціонування сил цивільного захисту матеріально-технічної бази i забезпечення готовності таких формувань до дій за призначенням [18, п. 5 ст. 20].

Матеріальний резерв - запас будівельних i пальномастильних матеріалів, лікарських засобів та виробів медичного призначення, продовольства, техніки, технічних засобів та інших матеріальних цінностей, призначених для запобігання i 


\section{Науковий вісник : Державне управління №1 (7) 2021}

ліквідації наслідків надзвичайних ситуацій, надання допомоги постраждалому населенню, проведення невідкладних відновлювальних робіт і заходів [18].

Крім того, згідно ст. Закону України «Про державний матеріальний резерв» для забезпечення першочергових робіт під час ліквідації наслідків надзвичайних ситуацій може використовуватися державний матеріальний резерв.

Державний матеріальний резерв в сучасних економічних умовах $\epsilon$ важливим компонентом системи забезпечення національної безпеки, a також одним 3 найважливіших інструментів держави по оперативному реагуванню на несприятливі та різкі зміни економічної та соціально-політичної ситуації в країні та у світі, виникнення нових загроз, в тому числі терористичних, природні та техногенні катастрофи [20]. До складу державного резерву входять:

мобілізаційний резерв - запаси матеріально-технічних та сировинних ресурсів, призначених для забезпечення розгортання виробництва військової та іншої промислової продукції, ремонту військової техніки та майна в особливий період, розгортання у воєнний час робіт по відновленню залізничних та автомобільних шляхів, морських та річкових портів, аеродромів, ліній і споруд зв'язку, газо-, нафтопродуктопроводів, систем енерго- i водопостачання для організації безперебійної роботи промисловості, транспорту i зв'язку, подання медичної допомоги;

запаси сировинних, матеріально-технічних і продовольчих ресурсів для забезпечення стратегічних потреб держави;

запаси матеріально-технічних ресурсів для виконання першочергових робіт під час ліквідації наслідків надзвичайних ситуацій та для виконання інших заходів, передбачених законодавством [20].

Також, відповідно до статті 98 Кодексу Цивільного захисту України, створюються оперативний матеріальний резерв, відомчий, регіональний, місцевий та об'єктовий. Ціль формування перелічених резервів - це забезпечення запобігання i ліквідації наслідків надзвичайних ситуацій та надання 
термінової невідкладної допомоги постраждалому населенню (оперативний); у відповідній галузі економіки (відомчий резерв); надання термінової допомоги постраждалому населенню в рамках окремої території чи регіону (регіональний та місцевий); проведення невідкладних відновлювальних робіт (об'єктовий).

Створення, утримання та поповнення матеріальних резервів здійснюється: оперативного - за рахунок коштів державного бюджету через Державну службу України 3 надзвичайних ситуацій (далі - ДСНС); відомчого - за рахунок коштів державного бюджету через відповідні центральні органи виконавчої влади; регіонального та місцевого - за рахунок коштів бюджету Автономної Республіки Крим i місцевих бюджетів; об'єктового - за рахунок власних коштів підприємств. Створення, утримання та поповнення матеріальних резервів може здійснюватися також за рахунок добровільних пожертвувань фізичних i юридичних осіб, благодійних організацій та об'єднань громадян, інших не заборонених законодавством джерел [18].

Розрахунок необхідних (достатніх) матеріальних резервів із застосуванням відповідних математичних формул для підвищення ефективності дій підрозділів сил цивільного захисту при ліквідації наслідків надзвичайних ситуацій як інструменту механізму державного управління силами цивільного захисту обгрунтовано та представлено колективом авторів у складі В. Єлісєєва, А. Пруського, В. Тищенка, С. Власенка [22].

Створення та використання матеріальних резервів для запобігання i ліквідації наслідків надзвичайних ситуацій визначено відповідним Порядком [19]. Згідно з порядком, наказом ДСНС у 2019 році затверджено «Положення про оперативний матеріальний резерв ДСНС для запобігання i ліквідації наслідків надзвичайних ситуацій та надання термінової невідкладної допомоги постраждалому населенню». Проте, згодом на підставі висновків, викладених у листі Міністерства юстиції України від 17.09.2020 № 41503/66335-61-20/10.1.2, даний наказ втратив чинність. 


\section{Науковий вісник : Державне управління №1 (7) 2021}

У 2020 році ДСНС розроблено оновлені Методичні рекомендації щодо створення та використання матеріальних резервів для запобігання виникненню надзвичайних ситуацій i ліквідації їх наслідків, які містять основні положення щодо створення, зберігання, поповнення, використання матеріальних резервів усіх рівнів (крім державного) для запобігання виникненню надзвичайних ситуацій і ліквідації їх наслідків та направлені на підвищення рівня захисту населення і територій від $\mathrm{HC}[23]$.

Розглянемо основні відмінності оновлених методичних рекомендацій від Методичних рекомендацій щодо створення та використання матеріальних резервів для запобігання і ліквідації наслідків надзвичайних ситуацій, які були розроблені ДСНС у 2017 році та схвалені науково-технічною радою Українського науково-дослідного інституту цивільного захисту 29 червня 2017 р. (протокол № 6).

Оновлені методрекомендації конкретизують мету їх створення, а саме для невідкладного залучення для здійснення заходів інженерного, радіаційного, хімічного, медичного, медикобіологічного і протипожежного захисту.

Поряд з положеннями про створення матеріальних резервів, які відповідають попередній редакції, акцентується увага на необхідності створення матеріального резерву засобів зв'язку незалежно від характеру походження НС. Адже, комунікація $є$ головною умовою безперебійного управління органами та силами задіяними в ліквідації наслідків НC і тому має передбачати своєчасний надійний зв'язок.

Раніше поновлення матеріальних резервів здійснювалося відповідно до графіка накопичення, форма та використання якого згідно нових рекомендацій не передбачається. Зазначено, що придбання матеріальних цінностей враховується під час формування бюджетних запитів та паспортів бюджетних програм для забезпечення своєчасного фінансування видатків 3 державного бюджету або фінансових планів суб'єкта господарювання. 
У вимогах до зберігання матеріальних цінностей відбулися уточнення щодо термінів звернення до компетентних органів для проведення відповідних (лабораторних) випробувань матеріальних цінностей та подовження їх кінцевого терміну зберігання. Відтак, такі звернення необхідно здійснювати за 3-4 місяці до кінцевих термінів зберігання, які мають відслідковувати працівники, залучені до питань зберігання резервів.

Деталізовано також напрями використання матеріальних резервів для запобігання виникненню НС та проведення робіт 3 ліквідації наслідків НС. У першому випадку матеріальні цінності використовуються для здійснення заходів щодо підвищення стійкості об’єктів інфраструктури, будівель і споруд, берегоукріплювальних робіт, проведення евакуаційних заходів, які включають перевезення громадян у безпечні зони з епіцентру можливої НС або можливого ураження, тобто проведення заходів направлених на мінімізацію факторів впливу НС на навколишнє середовище 3 метою збереження життя та здоров'я громадян, об'єктів інфраструктури і майна [23]. При ліквідації наслідків НC, матеріальні резерви забезпечують проведення аварійнорятувальних робіт, населенню в умовах НС надають життєво необхідні продукти та інші засоби, необхідну допомогу постраждалим тощо. Крім того, відпуск матеріальних цінностей може здійснюватися задля освіження або заміни матеріального резерву. Матеріальні запаси 3 матеріальних резервів, які потребують оновлення можуть спрямовуватися на задоволення поточних потреб на підставі рішення керівників, які управляють організацією, що створила такий резерв, або ж реалізуються 3 дотриманням положень законодавства України. Кошти, отримані від продажу матеріальних запасів, використовуються для оновлення матеріального резерву шляхом придбання аналогічних матеріальних цінностей, про що в попередній редакції методики не йшлося.

3 метою поглиблення розуміння та надання методичної підтримки відповідальним виконавцям 3 питань фінансового відображення використання коштів резервного бюджету, списання та відчуження окремих складових матеріальних 
резервів, нормативно-правова база з питань цивільного захисту, що пов'язана із їх створенням, зберіганням, поповненням та використанням доповнена відповідними постановами Кабінету Міністрів України [24-26]:

Ці нормативні документи визначають напрями використання коштів резервного фонду державного бюджету та місцевого бюджету і встановлює процедури, пов'язані з виділенням коштів резервного фонду відповідного бюджету та звітуванням про їх використання [24]; особливості списання об'єктів державної власності, а саме об'єктів незавершеного будівництва, основних фондів, інших необоротних матеріальних активів) [25]; механізм та способи відчуження об'єктів державної власності [26].

Враховуючи проведений аналіз стану нормативно-правового забезпечення 3 питань створення, поновлення, використання тощо матеріальних резервів (матеріально-технічного потенціалу ЄДСЦЗ), варто зазначити, що дане питання в достатній мірі регламентоване на законодавчому рівні. Це дає змогу керівникам відповідних органів виконавчої влади, органів місцевого самоврядування та суб'єктів господарювання 3 чіткою послідовністю створювати, поновлювати, використовувати тощо матеріальні цінності i тим самим забезпечувати розвиток матеріально-технічного ресурсу відповідної ланки СДСЦЗ.

Однак на практиці, відповідно до Звіту Рахункової Палати України за 2019 рік, аудитом ефективності управління матеріальними цінностями державного матеріального резерву виявлено низку порушень і недоліків, які негативно вплинули на процес управління матеріальними цінностями державного матеріального резерву на загальну суму 652,7 млн гривень. Крім того, з порушенням вимог Закону України «Про державний матеріальний резерв» та Інструкції про оформлення операцій 3 матеріальними цінностями державного матеріального резерву до державного резерву закладалися матеріальні цінності без належного підтвердження якості. Таких операцій здійснено на загальну суму 318,4 млн гривень [15].

Отже, підтверджений звітом Рахункової Палати України незадовільний фактичний стан матеріально-технічного ресурсу, у 
тому числі СДСЦЗ беззаперечно призведе до неможливості вчасного забезпечення, або неналежного забезпечення реалізації заходів із запобігання чи ліквідації наслідків в умовах надзвичайних ситуацій.

Напрямами удосконалення державного управління розвитком ресурсного потенціалу ЄДСЦЗ в цілому, своєчасному накопиченню, оновленню, ефективному використанню матеріально-технічного ресурсу може стати система внутрішнього (функціонує в ДСНС [28]) та зовнішнього контролю, яка повинна бути розроблена та поширена на всю систему органів управління ЄДСЦЗ; розроблення методики ефективного управління та оцінювання стану розвитку ресурсного потенціалу в цілому.

Висновки та напрями подальших досліджень. Перспективним методологічним підходом до удосконалення державного управління ЄДСЦЗ вважаємо ресурсний підхід.

Ресурсний потенціал СДСЦЗ - це комплекс науковотехнічного, морального, кадрового, фінансового, матеріальнотехнічного, інформаційного, інституційного (соціальноінфраструктурного) потенціалу, що може бути застосований органами управління для виконання її функцій.

Матеріально-технічний ресурс (потенціал) - це сукупність матеріальних i технічних засобів, технологій, систем, що створюють систему ресурсного забезпечення функціонування СДСЦЗ. В свою чергу, ресурсне забезпечення - це система організаційно-економічних відносин між суб'єктами забезпечення цивільного захисту, спрямованих на своєчасне та ефективне забезпечення функціонування СДСЦЗ необхідними ресурсами.

Нормативно-правове забезпечення розвитку матеріальнотехнічного потенціалу СДСЦЗ в достатній мірі регламентований. Однак прорахунки в управлінні ним свідчать про необхідність розробки дієвих механізмів ефективного управління та оцінювання стану розвитку ресурсного потенціалу ЄДСЦЗ в цілому, введення системи внутрішнього та зовнішнього 
контролю за процесом створення, накопичення, відновлення матеріально-технічного потенціалу ЄДСЦЗ.

Критеріями оцінювання стану розвитку ресурсного потенціалу ЄДСЦЗ може стати доцільність та ефективність використання будь-яких із наявних ресурсів, а також ефективність управління на всіх рівнях - державному, функціональному, територіальному, об'єктовому.

Напрямом подальшого дослідження може стати розробка алгоритму розрахунку рівня ефективності управління ресурсним потенціалом ЄДСЦЗ.

\section{Список використаних джерел}

1. Ресурсний потенціал регіону : навч. посіб. / авт.-упоряд. : М. К. Орлатий, С. А. Романюк, І. О. Дегтярьова та ін. ; за заг. ред. М. К. Орлатого. К. : НАДУ, 2014. 724 с. URL : http://academy.gov.ua/NMKD/library_nadu/Navch_Posybniky/3c11f746163b-4003-849a-2d9d85223a7a.pdf (дата звернення 20.12.2020).

2. Литвиновський $€$. Ю. Деякі результати спостереження за організацією функціонування територіальної підсистеми єдиної державної системи цивільного захисту. Науковий вісник : державне управління. №4(6). 2020. С. 160-185. URL : https://doi.org/10.32689/2618-0065-2020-4(6)-160-185 (дата звернення 30.12.2020)

3. Андреєв C. А. Методологічні підходи до дослідження інституціональних засад розвитку державних систем цивільного захисту. Державне управління: теорія та практика №1. 2016. C. 33 - 45. URL : http://www.e-patp.academy.gov.ua/2016_1/5.pdf (дата звернення 20.12.2020).

4. Андреєв С. О. Інституціональні засади розвитку державних систем цивільного захисту: автореф. дис. ... д. держ. упр.: 25.00.02. К.: НАДУ при Президентові України, 2017. 36 с.

5. Титаренко А. В. Методологічні засади державного управління сферою захисту населення і територій від надзвичайних ситуацій. Вісник Національного університету иивільного захисту Украӥни. Серія : Державне управління. 2016. Вип. 1. С. 216 - 222. URL : http://nbuv.gov.ua/UJRN/VNUCZUDU_2016_1_34 (дата звернення : 20.12.2020). 


\section{Науковий вісник : Державне управління №1 (7) 2021}

6. Лещенко О. Я. Трансформація системи цивільного захисту України в умовах сучасних воєнно-політичних конфліктів гібридного типу : автореф. дис. ... канд. політ. наук. URL : https://niss.gov.ua/sites/default/files/2019-12/aref_leschenko_fin_3-.pdf (дата звернення : 20.12.2020).

7. Волянський П. Б. Державне управління медичним захистом населення від наслідків надзвичайних ситуацій в Україні : монографія. К., 2013. 360 с.

8. Терент'єва А. В. Дослідженість проблеми стандартизації прийняття управлінських рішень в умовах надзвичайних ситуацій. Науковий вісник : Державне управління. №2 (4). С. 340 - 355. URL : https://doi.org/10.32689/2618-0065-2020-2(4)-340-355

9. Терент'єва А. В. Економіко-математична модель управління матеріальними ресурсами Державної служби медицини катастроф. Збірник прачь Української академії державного управління при Президенті України. Випуск 1. 2001. Київ : УАДУ, 2001.

10. Терент'єва А. В. Управління ресурсами при подоланні наслідків надзвичайних ситуацій. Електронний науковий фаховий журнал "Державне управління: удосконалення та розвиток" № 3. 2009. URL : http://www.dy.nayka.com.ua/?op=1\&z=47

11. Василик Н. М. Оцінка ефективності управління ресурсним потенціалом підприємства. Економічний аналіз. Тернопіль, 2018. Том 28. № 3. С. 154 - 161 .

12. Ресурсний потенціал регіону : навч. посіб. / авт.-упоряд. : М. К. Орлатий, С. А. Романюк, І. О. Дегтярьова та ін. ; за заг. ред. М. К. Орлатого. - К. : НАДУ, 2014. 724 с. URL : http://academy.gov.ua/NMKD/library nadu/Navch Posybniky/3c11f746163b-4003-849a-2d9d85223a7a.pdf (дата звернення 20.12.2020).

13. Кадровий потенціал суб'єктів забезпечення цивільного захисту : регіональний аспект : методичний посібник / Литвиновський Є.Ю. та ін.; за заг. ред. Волянського П. Б. Запоріжжя, 2014. 119 с. URL : http://lib.idundcz.dsns.gov.ua/weblib/books/Litvinovskiy E_Yu_/06.pdf (дата зверення 20.12.2020).

14. Методологія наукових досліджень 3 державного управління : хрестоматія / упоряд. : С. В. Загороднюк, О. Л. Євмєшкіна, В. В. Лещенко ; за заг. ред. К. О. Ващенка. К. : НАДУ, 2014. 180с.

15. Методологія державного управління : словник-довідник / уклад. : В. Д. Бакуменко (кер. авт. кол.) ; за заг. ред. В. І. Лугового, В. М. Князєва. К. : Вид-во НАДУ, 2004. 196 с. 


\section{Науковий вісник : Державне управління №1 (7) 2021}

16. Теоретичні та організаційно-методичні засади проектування освітньої діяльності навчально-методичних установ цивільного захисту : монографія (з електрон. дод.) / Бегун В. В.; за заг. ред. Литвиновського Є.Ю. Вид. 2, переробл. Львів : Кругозір, 2017. 230 с.

17. Енциклопедія державного управління : у 8 т. / Нац. акад. держ. упр. при Президентові України : наук.-ред. колегія : Ю. В. Ковбасюк (голова) та ін. К. : НАДУ, 2011. Т. 2 : Методологія державного управління / наук.-ред. колегія : Ю. П. Сурмін (співголова), П. І. Надолішній (співголова) та ін. 2011. 692 с.

18. Кодекс цивільного захисту України: Закон України від 2.10.2012 5403-VI // База даних “Законодавство України” / ВР України. https://zakon.rada.gov.ua/laws/show/5403-17\#Text : (дата звернення: 20.12.2020).

19. Про затвердження Порядку створення та використання матеріальних резервів для запобігання і ліквідації наслідків надзвичайних ситуацій : постанова Кабінету Міністрів України» від 30.09.2015 № 775 // База даних «Законодавство України» / ВР України. URL : https://zakon.rada.gov.ua/laws/show/775-2015\%D0\%BF\#Text (дата звернення 20.12.2020).

20. Про державний матеріальний резерв : Закон України від 24.01.1997 № 51/97-вр // База даних «Законодавство України» / ВР України. URL : $\quad$ https://zakon.rada.gov.ua/laws/main/51/97\%D0\%B2\%D1\%80\#Техt (дата звернення 20.12.2020).

21. Андрієнко М. В. Механізми державного управління сферою пожежної безпеки в Україні: дис. ... д. держ. упр.: 25.00.02 / Класичний приватний університет. Запоріжжя, 2016. 458 с.

22. Єлісєєв В., Пруський А., Тищенко В., Власенко Є. Методика розрахунку матеріальних резервів як інструмент механізму державного управління силами цивільного захисту. Науковий вісник: Державне управління. 2020. № 4 (6). С. $122-142$.

23. Методичні рекомендації щодо створення та використання матеріальних резервів для запобігання виникненню надзвичайних ситуацій і ліквідації їх наслідків / Офіційний сайт Державної служби України 3 надзвичайних ситуацій. URL: https://www.dsns.gov.ua/ua/Metodichni-rekomendaciyi-z-pitanmaterialnih-rezerviv.html. (дата звернення : 20.12.2020).

24. Про затвердження Порядку використання коштів резервного фонду бюджету : постанова Кабінету міністрів України від 29.03.2002 № 415 // База даних «Законодавство України» / BP України. URL : 
https://zakon.rada.gov.ua/laws/show/415-2002-\%D0\%BF\#Text (дата звернення : 20.12.2020).

25. Про затвердження Порядку списання об'єктів державної власності : постанова Кабінету міністрів України від 08.11.2007 № 1314 // База даних «Законодавство України» / BP України. URL : https://zakon.rada.gov.ua/laws/show/1314-2007-\%D0\%BF\#Text (дата звернення : 20.12.2020).

26. Про затвердження Порядку відчуження об'єктів державної власності : постанова Кабінету міністрів України від 06.06.2007 № 803 // База даних «Законодавство України» / BP України. URL : https://zakon.rada.gov.ua/laws/show/803-2007-\%D0\%BF\#Text (дата звернення : 20.12.2020).

27. Звіт Рахункової Палати України за 2019 рік / Офіційний сайт рахункової палати України. URL: https://rp.gov.ua/Activity/Reports.

28. Кравченко Ю. П. Внутрішній контроль - атрибут ефективного управління бюджетною установою Державної служби України 3 надзвичайних ситуацій. Науковий вісник : Державне управління. 2020. № 3 (5). C. $101-109$.

\section{References}

1. Resursnyi potentsial rehionu [Estimation of efficiency of management of resource potential of the enterprise.] : navch. posib. / avt.-uporiad. : M. K. Orlatyi, S. A. Romaniuk, I. O. Dehtiarova ta in. ; za zah. red. M. K. Orlatoho. K. : NADU, 2014. 724 s. URL : http://academy.gov.ua/NMKD/library_nadu/Navch_Posybniky/3c11f746163b-4003-849a-2d9d85223a7a.pdf [in Ukrainian].

2. Lytvynovskyi Ye. Yu. Deiaki rezultaty sposterezhennia za orhanizatsiieiu funktsionuvannia terytorialnoi pidsystemy yedynoi derzhavnoi systemy tsyvilnoho zakhystu. [Some results of observation of the organization of functioning of the territorial subsystem of the unified state system of civil defense]. Naukovyi visnyk : derzhavne upravlinnia. №4(6). 2020. S. 160185. URL : https://doi.org/10.32689/2618-0065-2020-4(6)-160-185 [in Ukrainian].

3. Andreiev S. A. Metodolohichni pidkhody do doslidzhennia instytutsionalnykh zasad rozvytku derzhavnykh system tsyvilnoho zakhystu [Methodological approaches to the study of institutional foundations for the development of state civil protection systems]. Derzhavne upravlinnia: teoriia ta praktyka №1. 2016. S. 33 - 45. URL : http://www.e-patp.academy.gov.ua/2016_1/5.pdf [in Ukrainian]. 


\section{Науковий вісник : Державне управління №1 (7) 2021}

4. Andreiev S. O. Instytutsionalni zasady rozvytku derzhavnykh system tsyvilnoho zakhystu [Institutional principles of development of state systems of civil protection]: avtoref. dys. ... d. derzh. upr.: 25.00.02. K.: NADU pry Prezydentovi Ukrainy, 2017. 36 s. [in Ukrainian].

5. Tytarenko A. V. Metodolohichni zasady derzhavnoho upravlinnia sferoiu zakhystu naselennia i terytorii vid nadzvychainykh sytuatsii [Methodological principles of state management in the field of protection of the population and territories from emergencies]. Visnyk Natsionalnoho universytetu tsyvilnoho zakhystu Ukrainy. Seriia : Derzhavne upravlinnia. 2016. Vyp. 1. S. 216 - 222. URL : http://nbuv.gov.ua/UJRN/VNUCZUDU_2016_1_34 [in Ukrainian].

6. Leshchenko O. Ya. Transformatsiia systemy tsyvilnoho zakhystu Ukrainy v umovakh suchasnykh voienno-politychnykh konfliktiv hibrydnoho typu [Transformation of the civil defense system of Ukraine in the conditions of modern military-political conflicts of hybrid type] URL : https://niss.gov.ua/sites/default/files/2019-12/aref_leschenko_fin_3-.pdf [in Ukrainian].

7. Volianskyi P. B. Derzhavne upravlinnia medychnym zakhystom naselennia vid naslidkiv nadzvychainykh sytuatsii $\mathrm{v}$ Ukraini : monohrafiia [State Department of Medical Protection of the Population from the Consequences of Emergencies in Ukraine]. K., 2013. 360 s. [in Ukrainian].

8. Terentieva A. V. Doslidzhenist problemy standartyzatsii pryiniattia upravlinskykh rishen $\mathrm{v}$ umovakh nadzvychainykh sytuatsii [Research of the problem of standardization of managerial decision-making in emergency situations]. Naukovyi visnyk : Derzhavne upravlinnia. №2 (4). S. 340 - 355. URL : https://doi.org/10.32689/2618-0065-2020-2(4)-340355 [in Ukrainian].

9. Terentieva A. V. Ekonomiko-matematychna model upravlinnia materialnymy resursamy Derzhavnoi sluzhby medytsyny katastrof [Economic and mathematical model of material resources management of the State Disaster Medicine Service]. Zbirnyk prats Ukrainskoi akademii derzhavnoho upravlinnia pry Prezydenti Ukrainy. Vypusk 1. 2001. Kyiv : UADU, 2001. [in Ukrainian].

10. Terentieva A. V. Upravlinnia resursamy pry podolanni naslidkiv nadzvychainykh sytuatsii [Resource management in dealing with the consequences of emergencies]. Elektronnyi naukovyi fakhovyi zhurnal "Derzhavne upravlinnia: udoskonalennia ta rozvytok № 3. - 2009 URL : http://www.dy.nayka.com.ua/?op=1\&z=47 [in Ukrainian]. 
11. Vasylyk N. M. Otsinka efektyvnosti upravlinnia resursnym potentsialom pidpryiemstva [Estimation of efficiency of management of resource potential of the enterprise]. Ekonomichnyi analiz. Ternopil, 2018. Tom 28. № 3. S. 154 - 161 [in Ukrainian].

12. Resursnyi potentsial rehionu : navch. Posib [Estimation of efficiency of management of resource potential of the enterprise]. / avt.-uporiad. : M. K. Orlatyi, S. A. Romaniuk, I. O. Dehtiarova ta in. ; za zah. red. M. K. Orlatoho. K. : NADU, 2014. 724 s. URL : http://academy.gov.ua/NMKD/library_nadu/Navch_Posybniky/3c11f746163b-4003-849a-2d9d85223a7a.pdf [in Ukrainian].

13. Kadrovyi potentsial subiektiv zabezpechennia tsyvilnoho zakhystu : rehionalnyi aspekt : metodychnyi posibnyk [Personnel potential of subjects of providing civil protection: regional aspect: methodical manual] / Lytvynovskyi Ye.Iu. ta in.; za zah. red. Volianskoho P. B.

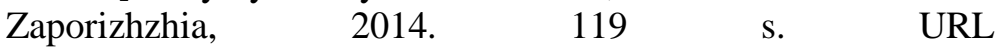
http://lib.idundcz.dsns.gov.ua/weblib/books/Litvinovskiy E_Yu_/06.pdf [in Ukrainian].

14. Metodolohiia naukovykh doslidzhen $\mathrm{z}$ derzhavnoho upravlinnia : khrestomatiia [Methodology of public administration research: a textbook] / uporiad. : S. V. Zahorodniuk, O. L. Yevmieshkina, V. V. Leshchenko ; za zah. red. K. O. Vashchenka. K. : NADU, 2014. 180 s. [in Ukrainian].

15. Metodolohiia derzhavnoho upravlinnia : slovnyk-dovidnyk [Methodology of public administration: dictionary-reference book] / uklad. : V. D. Bakumenko (ker. avt. kol.) ; za zah. red. V. I. Luhovoho, V. M. Kniazieva. K. : Vyd-vo NADU, 2004. 196 s. [in Ukrainian].

16. Teoretychni ta orhanizatsiino-metodychni zasady proektuvannia osvitnoi diialnosti navchalno-metodychnykh ustanov tsyvilnoho zakhystu : monohrafiia (z elektron. dod.) [Theoretical and organizational-methodical bases of designing of educational activity of educational-methodical establishments of civil protection: monograph] / Behun V. V.; za zah. red. Lytvynovskoho Ye.Iu. Vyd. 2, pererobl. Lviv : Kruhozir, 2017. 230 s. [in Ukrainian].

17. Entsyklopediia derzhavnoho upravlinnia [Encyclopedia of Public Administration]: u 8 t. / Nats. akad. derzh. upr. pry Prezydentovi Ukrainy ; nauk.-red. kolehiia : Yu. V. Kovbasiuk (holova) ta in. K. : NADU, 2011. T. 2 : Metodolohiia derzhavnoho upravlinnia [Methodology of public administration] / nauk.-red. kolehiia : Yu. P. Surmin (spivholova), P. I. Nadolishnii (spivholova) ta in. 2011. 692 s. [in Ukrainian]. 


\section{Науковий вісник : Державне управління №1 (7) 2021}

18. Kodeks tsyvilnoho zakhystu Ukrainy : Zakon Ukrainy vid 02.10.2012 № 5403-VI. [Law of Ukraine "Code of Civil Protection of Ukraine" from October 2, 2012 № 5403-VI] (n.d.) zakon.rada.gov.ua Retrieved from https://zakon.rada.gov.ua/laws/show/5403-17\#Text [in Ukrainian].

19. Pro zatverdzhennia Poriadku stvorennia ta vykorystannia materialnykh rezerviv dlia zapobihannia I likvidatsii naslidkiv nadzvychainykh sytuatsii : Postanova Kabinetu Ministriv Ukrainy [Decree of the Cabinet of Ministers of Ukraine "On approval of the Procedure for the creation and use of material reserves for the prevention and elimination of the consequences of emergencies"] (n.d.) zakon.rada.gov.ua Retrieved from https://zakon.rada.gov.ua/laws/main/775-2015-\%D0\%BF [in Ukrainian].

20. Pro derzhavnyi materialnyi rezerv : Zakon Ukrainy vid 24.01.1997 № 51/97-VR. [Law of Ukraine "About the state material reserve" from January 24, 1997 № 51/97-VR] (n.d.) zakon.rada.gov.ua Retrieved from https://zakon.rada.gov.ua/laws/show/51/97-\%D0\%B2\%D1\%80\#Text [in Ukrainian].

21. Andriienko, M. V. (2016) Mekhanizmy derzhavnoho upravlinnia sferoiu pozhezhnoi bezpeky v Ukraini [Mechanisms of state management in the field of fire safety in Ukraine]. Doctor's thesis. Zaporizhzhia: Klasychnyi pryvatnyi universytet [in Ukrainian].

22. Yelisieiev, V., Pruskyi, A., Tyshchenko, V. \& Vlasenko Ye. (2020) Metodyka rozrakhunku materialnykh rezerviv yak instrument mekhanizmu derzhavnoho upravlinnia sylamy tsyvilnoho zakhystu [Method of calculation of material reserves as an tool of the mechanism of public management of civil protection forces] Naukovyi visnyk: derzhavne upravlinnia - Scientific Bulletin: Public Administration, 4 (6), 122-142 [in Ukrainian].

23. Metodychni rekomendatsii shchodo stvorennia ta vykorystannia materialnykh rezerviv dlia zapobihannia i likvidatsii naslidkiv nadzvychainykh sytuatsii [Methodical recommendations on the creation and use of material reserves to prevent and eliminate the consequences of emergencies]. (n.d.) dsns.gov.ua Retrieved from https://www.dsns.gov.ua/ua/Metodichni-rekomendaciyi-z-pitanmaterialnih-rezerviv.html [in Ukrainian].

24. Pro zatverdzhennia Poriadku vykorystannia koshtiv rezervnoho fondu biudzhetu [About the statement of the Procedure for writing off of objects of the state property]: postanova Kabinetu ministriv Ukrainy vid 29.03.2002 № 415 // Baza danykh «Zakonodavstvo Ukrainy»/ VR Ukrainy. URL : https://zakon.rada.gov.ua/laws/show/415-2002$\%$ D0\%BF\#Text [in Ukrainian]. 
25. Pro zatverdzhennia Poriadku spysannia obiektiv derzhavnoi vlasnosti []About the statement of the Procedure for writing off of objects of the state property] : postanova Kabinetu ministriv Ukrainy vid 08.11.2007 № 1314 // Baza danykh «Zakonodavstvo Ukrainy» / VR Ukrainy. URL : https://zakon.rada.gov.ua/laws/show/1314-2007-\%D0\%BF\#Text ([in Ukrainian].

26. Pro zatverdzhennia Poriadku vidchuzhennia obiektiv derzhavnoi vlasnosti [About the statement of the Order of alienation of objects of the state property]: postanova Kabinetu ministriv Ukrainy vid 06.06.2007 № 803 // Baza danykh «Zakonodavstvo Ukrainy» / VR Ukrainy. URL : https://zakon.rada.gov.ua/laws/show/803-2007-\%D0\%BF\#Text Ukrainian].

27. Zvit Rakhunkovoi Palaty Ukrainy za 2019 rik [Report of the Accounting Chamber of Ukraine for 2019] (n.d.) rp.gov.ua Retrieved from https://rp.gov.ua/FinControl/FinReports/?id=150 [in Ukrainian].

28. Kravchenko, Yu.P. (2020) Vnutrishnii kontrol - atrybut efektyvnoho upravlinnia biudzhetnoiu ustanovoiu Derzhavnoi sluzhby Ukrainy $\mathrm{z}$ nadzvychainykh sytuatsii [Internal control - an attribute of effective budgetary institution's management of The State Emergency Service of Ukraine] Naukovyi visnyk: derzhavne upravlinnia Scientific Bulletin: Public Administration, 3 (5), 101-109 [in Ukrainian]. 


\title{
REGULATORY AND LEGAL SUPPORT OF THE DEVELOPMENT OF MATERIAL AND TECHNICAL POTENTIAL OF THE UNIFIED STATE SYSTEM OF CIVIL PROTECTION
}

\section{Podobied Ihor}

\begin{abstract}
The practice of responding to the emergency related to the spread of COVID-19 morbidity shows that the effectiveness of the unified state system of civil protection in everyday life, and especially when it is transferred to the state of emergency, depends on the availability of appropriate resource potential.

The purpose of the article is to analyze the state of regulatory and legal support of the development of material and technical potential of the unified state system of civil protection. Based on the analysis of different methodological approaches to public administration in the sphere of civil protection, the application of a resource approach to the functioning of the unified state system of civil protection is proposed as promising. This allows you to take into account forecasts for its development, to predict the use of new and alternative types of resources. The author's understanding of the definitions "resource", "potential", "resource potential", "material and technical resource" is given.

The article gives the author's definition of the resource potential of the unified state system of civil protection as a complex of scientific and technical, moral, organizational, personnel, financial, logistical, educational, informational, institutional (social and infrastructural) potential that can be used by governing bodies to perform its functions. Material and technical resource (potential) is understood as a set of material and technical means, technologies, systems that create a system of resource support for the functioning of unified state system of civil protection. In essence, the material and technical resource consists of the current resource used by the unified state system of civil protection, as well as material reserves, which according to the law are divided into operational, departmental, regional and object. The state material reserve may also be involved in the implementation of emergency response tasks. It is determined that the normative and legal support for the development of material and technical potential of the of unified state system of civil protection is sufficiently regulated. However, it has been established that the actual condition of the material and technical resource of the of unified state system of civil protection does not provide timely, proper implementation of measures to prevent or eliminate the consequences in emergencies. Criteria for assessing the state of development of the resource potential of the unified state system of civil protection are the feasibility and efficiency of using any of the available resources, the effectiveness of management at all levels state, functional, territorial, object. The direction of further development of algorithm of calculating the level of management efficiency of development of resource potential of unified state system of civil protection is defined.
\end{abstract}

Keywords: public administration, resource potential, structure of resource potential, unified state system of civil protection, material reserves, emergency, civil protection, regulatory and legal support. 